\title{
DARLING-HAMMOND, Linda. The Flat World and Education: How America's Commitment to Equity Will Determine Our Future. New York: Teachers College Press, 2010, 394 p.
}

Sonia Dias

Doutoranda em Educação (FE-USP), especialista em Política e Planejamento de Educação pela Vanderbit University. Atua em projetos na área de educação, especialmente em materiais de educação para professores e gestores públicos.
Linda Darling-Hammond tem uma carreira consolidada na área de educação nos Estados Unidos, foi professora de escola pública, é doutora em Educação Urbana e é atualmente professora na Universidade de Stanford. Foi co-diretora do Centro Nacional para Reestruturação da Educação, da Comissão Nacional de Ensino e o Futuro da América, além de ter sido consultora-chefe de Educação do governo Obama. É ainda autora de mais de 12 livros e mais de 300 artigos sobre educação.

Com toda essa bagagem, em seu premiado livro The Flat World and Education: How America's Commitment to Equity Will Determine Our Future ( $O$ mundo plano e a educação: como o compromisso com a equidade vai determinar o nosso futuro), a professora Linda Darling-Hammond analisa de maneira abrangentee aprofundada dados de financiamento educacional, exames de larga escala e formação de professores, além de oferecer algumas recomendações para uma reforma escolar que realmente faça frente às desigualdades educacionais tanto do ponto de vista da escola quanto da gestão pública da educação.

Partindo do ponto de vista das desigualdades educacionais, seu livro analisa como essas têm sido historicamente construídas, o impacto do uso dos testes de larga escala nas análises educacionais, o impacto dos recursos destinados à educação e como países como Finlândia, Cingapura e Coreia do Sul, além de experiências desenvolvidas nos Estados Unidos, têm enfrentado a questão da oferta de uma educação de qualidade 
para todos.

O titulo da publicação remete ao livro de "O mundo é plano", de Thomas Friedman, que trata da globalização. Para Linda Darling-Hammond, a imagem de que o mundo é plano a leva a refletir sobre o papel da escola pública em um mundo marcado pela abundancia de informação, avanços tecnológicos, rápidas mudanças na sociedade e acirrada competição internacional em todos os campos. A autora afirma que atualmente pelo menos $70 \%$ dos empregos nos Estados Unidos requerem conhecimentos e competências especializadas e que a natureza do trabalho deve continuar a mudar cada vez mais rapidamente. Para ela, a missão da escola hoje é preparar os estudantes para os trabalhos que ainda não existem, criando ideias e soluções para produtos e problemas que não foram identificados e usando tecnologias que ainda não foram totalmente desenvolvidas. Considerando a longa tradição de desigualdades na educação, a autora questiona se a sociedade americana será capaz de "enfrentar esse desafio oferecendo uma educação que desenvolva cada vez mais competências complexas - não apenas para uma pequena parcela de estudantes que tradicionalmente têm sido selecionados em escolas de elite, mas todos os alunos" (DARLING-HAMMOND, 2010, p. 2).

O livro tem como objetivo procurar responder esse desafio a partir do argumento de que é decisivo para os Estados Unidos construir um sistema educacional que tenha equidade e preparar todas as crianças para vida em uma sociedade baseada no conhecimento. Para a autora, a escola pública norte-americana ainda está estruturada em um modelo de preparação para o trabalho industrial, estabelecido no século XX.

COMO AS DEsigualdades SÃo CONStRuídas E CAMinhos PARA O SEU ENFRENTAMENTO

A autora analisa os dados do Programa Internacional de Avaliação dos Estudantes (Pisa), que demonstram que o desempenho dos alunos norteamericanos tem sido abaixo da média dos países da Organização para Cooperação e Desenvolvimento Econômico (OCED), e que países como Finlândia e Coreia do Sul têm apresentado índices muito melhores. Para ela, as desigualdades têm papel preponderante sobre esses dados, pois enquanto os alunos brancos e asiáticos recebem pontuação acima da média OCED, os estudantes afro-americanos e hispânicos estão bem abaixo dessa média. Mas, para Linda Darling-Hammond, essa segregação não é nova, ela vem sendo construída ao longo de décadas por meio do descaso e de 
políticas públicas que reproduzem as desigualdades. Ela dá um exemplo de 1857 em que um grupo de líderes afro-americanos realizou um protesto para que o governo do estado de Nova lorque realizasse uma investigação para averiguar por que o Conselho Escolar do Estado gastava 16 dólares por crianças brancas e apenas 1 centavo para crianças negras matriculadas nas escolas públicas (p. 29). Segundo a autora, apesar de diversas iniciativas para superar essa situação, ainda persistem as disparidades no montante de recursos destinados às escolas, de acordo com sua localização e população, de maneira que as escolas em bairros afluentes - com baixos índices de diversidade entre os alunos -, recebem maiores recursos, possuem menor rotatividade de professores e melhor infraestrutura.

Para Darling-Hammond, os altos índices de desempenho no Pisa estão relacionados a políticas educacionais consistentes relacionadas à formação, remuneração e prestígio dos professores, financiamento educacional, infraestrutura das escolas, relação estreita entre a comunidade escolar, entre outros fatores. A autora mostra como a Finlândia, Coreia e Singapura reorganizaram seu sistema educacional para chegar aos resultados atuais. No caso da Finlândia, a mudança começou na década de 1970 com uma reestruturação na estrutura escolar, “eliminando os sistemas de testes após o ensino fundamental, e investindo na formação de professores altamente treinados, em currículo com foco na resolução de problemas, criatividade, aprendizagem independente e reflexão do aluno” (p. 165). Já na Coreia, os professores perdem apenas para os padres entre os profissionais mais confiáveis, além disso o salário médio dos professores está logo atrás dos médicos e acima dos engenheiros por conta do prestigio da profissão.

A autora também chama a atenção para a importância da qualificação do professor, que deve ser levada em conta na seleção de docentes, treinamento, indução, suporte, retenção, desenvolvimento profissional contínuo e condições de trabalho e a economia do ensino.

No capitulo final, Darling-Hammond utiliza como epígrafe a frase de John Dewey, que podem ser aplicadas à atualidade: “O que o melhor e mais sábio dos pais quer para seu próprio filho deve ser o que a comunidade almeja para todas as suas crianças. Qualquer outro ideal para nossas escolas é limitado e desagradável, age sobre nossa democracia e a destrói” (DEWEY, 1900, p. 3)².

Essas palavras referendam o percurso do livro em que a professora Darling-Hammond procura apresentar a miríade de aspectos envolvidos

DEWEY, John. The school and society. Chicago: University of Chicago Press, 1900. 
no enfrentamento das desigualdades na educação, chamando à ação, apresentando estatísticas e demonstrando como o futuro da nação está ligado ao destino dos jovens mais negligenciados. A professora apresenta cinco elementos-chave para o estabelecimento de sistemas educacionais capazes de enfrentar as desigualdades e elevar o desempenho dos estudantes: 1) Estabelecimento de objetivos de aprendizagem significativos, incluindo conteúdos contextualizados e competências necessárias para o século XXI; 2) Sistemas inteligentes de accountability (responsabilização no uso de recursos e compromisso com os resultados), focados na garantia de oportunidades de ensino e aprendizagem de qualidade; 3 ) recursos igualitários e adequados, oferecendo igualdade de condições para todos os alunos e escolas; 4) padrões profissionais elevados e apoio a todos os profissionais, incluindo suporte para o aperfeiçoamento, tutoria e acompanhamento profissional; 5) organização das escolas para aprendizagem de alunos e professores, de forma a facilitar a criação de currículo coerente com foco no conteúdo crítico e desenvolvimento de habilidades.

Para finalizar, Linda Darling-Hammond reafirma a necessidade urgente do enfrentamento das desigualdades não apenas para os Estados Unidos, mas para todas as nações que almejam o desenvolvimento:

Nenhuma sociedade pode prosperar em uma economia baseada no conhecimento tecnológico, privando grandes segmentos de sua população da aprendizagem. O caminho para o bem-estar mútuo baseia-se na oportunidade educacional. 0 foco central do futuro coletivo é o reconhecimento de que nossa capacidade de sobreviver e prosperar depende, em última análise, da garantia a todos daquilo que deve ser um direito inquestionável -o rico e inalienável direito de aprender (p.328). 